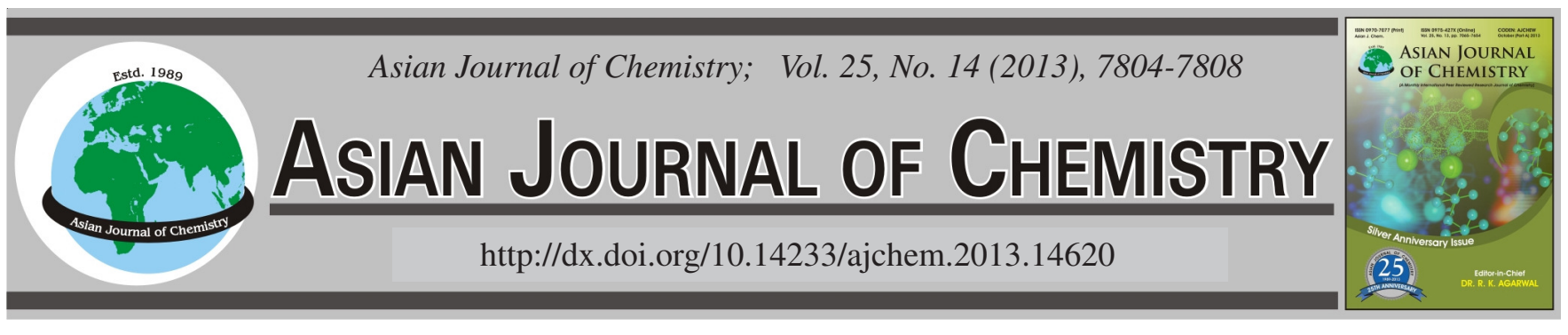

\title{
Qualitative and Quantitative Analysis of Mineral Elements in Four Different Typical Agricultural Soils in Lishu County, Jilin Province by X-ray Fluorescence Spectrometry
}

\author{
Shengliang Li, Yanbei Zhang and Yukui Rui*
}

College of Resources and Environmental Sciences, China Agricultural University, Beijing 100193, P.R. China

*Corresponding author: E-mail: ruiyukui@163.com

(Received: 25 September 2012;

Accepted: 15 July 2013)

AJC-13813

\begin{abstract}
To detect total mineral elements of four different representative agricultural soil types, which include black soil, brown soil, sandy soil and alluvial soil, collected from the surface layer of corn of Lishu county, Jilin province, P.R. China. X-ray fluorescence spectrometry was applied for qualitative and quantitative analysis. Qualitative analysis detected 33 elements, they are $\mathrm{Si}, \mathrm{Al}, \mathrm{Fe}, \mathrm{K}, \mathrm{Na}, \mathrm{Mg}, \mathrm{Ca}, \mathrm{Ti}$, phosphate (Px), Mn, S, Cl, Zr, Ba, V, Sr, Rb, Zn, Cr, La, Ni, Y, Mo, Pb, Co, Cu, Ga, Nb, Bi, Pt, Au, Ce, Sc, whereas Mo, Pb, Co, Cu, Ga, $\mathrm{Nb}, \mathrm{Bi}, \mathrm{Pt}, \mathrm{Au}, \mathrm{Ce}, \mathrm{Sc}$ was unique or just contained in few soil types, black soil contains the largest elemental varieties, sandy soil the less. Based on the different roles played in plant growing, as well as environmental concern, elements were classified into macronutrients ( $\mathrm{P}, \mathrm{K}, \mathrm{Ca}, \mathrm{Mg}, \mathrm{S}$ ), micronutrients ( $\mathrm{Fe}, \mathrm{Mn}, \mathrm{Cu}, \mathrm{Zn}, \mathrm{Mo}, \mathrm{Cl}, \mathrm{Ni}$ ), beneficial elements (Co, $\mathrm{Na}, \mathrm{Si}, \mathrm{Al}, \mathrm{Ce}, \mathrm{La}$, Y,), pollution elements (Cr, $\mathrm{Pb}$ ) and other elements ( $\mathrm{Ti}, \mathrm{Zr}, \mathrm{Ba}, \mathrm{V}, \mathrm{Sr}, \mathrm{Rb}, \mathrm{Ga}, \mathrm{Nb}, \mathrm{Bi}, \mathrm{Pt}, \mathrm{Au}, \mathrm{Sc}$ ). Comprehensive analysis showed that the elements measured were $50,48.7,46.1$ and $47.5 \%$ account for the total mass of black soil, sandy soil, brown soil and alluvial soil, respectively. In addition to organic matter, macronutrients, micronutrients and beneficial elements have made black soil a best candidate for crops planting. In conclusion, these data can be used as basic information on which development of sustainable agriculture and promotion of environmental conservation.
\end{abstract}

Key Words: Agricultural soils, X-ray fluorescence spectrometry, Elemental composition, Qualitative analysis, Quantitative analysis. |

\section{INTRODUCTION}

Surface agricultural soil is not only the matrix for plant growing, but also the main supplier of plant-available mineral elements ${ }^{1}$. Accordingly, they affect agricultural productivity, which was more pronounced in different soil types and at the same time determine a portion of the terrestrial environment ${ }^{2}$. Mineral element is essential nutrition for human health, plant growth and development ${ }^{3,4}$. The species of mineral elements in crops are various and according to content and functionality in crops, they can be divided into macronutrients, micronutrients, beneficial elements and pollution elements and other elements ${ }^{5,6}$. However, different soil types, which due to different soil parent materials, the impact of human activities, as well as temperature and humidity, contain different elements ${ }^{7}$. In this article, therefore, information on the elemental composition and contents of agricultural surface soils from different soil type are essential not only for the evaluation of inherent soil fertility and soil quality for a local conditions agriculture, but also for the understanding a variety of natural and anthropogenic processes from an environmental perspective.

The nondestructive property, easier sample preparation and simultaneous multi-element analysis capability of the
X-ray fluorescence (XRF) Spectrometry, makes it an attractive technique for the elemental analysis of a wide range of materials, Optimized operating conditions enhance the detection efficiency and improve the minimum detection limits ${ }^{8}$. The excellent properties mentioned above have made X-ray fluorescence spectrometry or improved a prominent way in soil elements determination, as well as sediments ${ }^{9-11}$. In this study, accounted for the acute sensitive and wide detection range, a Wavelength dispersive X-ray fluorescence spectrometry was utilized for qualitative and quantitative analysis.

\section{EXPERIMENTAL}

Soil samples and pre-treatment: All the 12 agricultural soil samples used in this study were collected in Lishu county, Jilin province from 4 soil types, which were black soil, sandy soil, brown soil and alluvial soil in order to have a homogenous representative sample. The desired soils for the experiment were air-dried by placing on kraft papers in a ventilated warm room for few days and the impurities such as stones and leaves were removed from them.

Sample processing and specimen preparation: Samples were crushed to pass through a 200-mesh nylon sieve prior, after this processing, baked at $105^{\circ} \mathrm{C}$ for $4 \mathrm{~h}$. When they were 
TABLE-1

ARITHMETIC MEAN, CONTENT RANGE OF TOTAL ELEMENTS IN DIFFERENT SOIL TYPE

\begin{tabular}{|c|c|c|c|c|c|c|c|c|}
\hline \multirow{2}{*}{ Element } & \multicolumn{2}{|c|}{ Black soil } & \multicolumn{2}{|c|}{ Sandy soil } & \multicolumn{2}{|c|}{ Brown soil } & \multicolumn{2}{|c|}{ Alluvial soil } \\
\hline & Mean & Range & Mean & Range & Mean & Range & Mean & Range \\
\hline $\mathrm{Si}$ & 30.5967 & $26.94-27.78$ & 33.2400 & $32.84-33.56$ & 26.6200 & $26.53-26.78$ & 29.8567 & $29.61-30.13$ \\
\hline $\mathrm{Al}$ & 9.5033 & $9.37-9.6$ & 8.0633 & $7.88-8.24$ & 9.9500 & $9.88-10.08$ & 8.7133 & 8.6-8.84 \\
\hline $\mathrm{Fe}$ & 2.6133 & $2.41-2.73$ & 1.4600 & $1.42-1.5$ & 3.3233 & $3.24-3.38$ & 2.0700 & $2.1-2.38$ \\
\hline $\mathrm{K}$ & 2.1767 & $2.16-2.19$ & 2.5200 & $2.5-2.56$ & 2.0567 & $2.04-2.08$ & 2.3333 & $2.3-2.38$ \\
\hline $\mathrm{Na}$ & 1.3200 & $1.25-1.45$ & 1.2633 & $1.25-1.28$ & 1.2600 & $1.1-1.53$ & 1.8167 & $1.77-1.9$ \\
\hline $\mathrm{Mg}$ & 1.3367 & $1.28-1.38$ & 0.8970 & $0.878-0.903$ & 1.1333 & $1.12-1.16$ & 0.9677 & $0.926-0.996$ \\
\hline $\mathrm{Ca}$ & 1.6033 & $1.54-1.7$ & 0.7313 & $0.719-0.747$ & 1.0667 & $1.04-1.08$ & 0.6761 & $0.957-0.974$ \\
\hline $\mathrm{Ti}$ & 0.4083 & $0.397-0.414$ & 0.2687 & $0.262-0.277$ & 0.4513 & $0.447-0.453$ & 0.3757 & $0.365-0.382$ \\
\hline Px & 0.1683 & $0.133-0.209$ & 0.0800 & $0.0772-0.083$ & 0.1127 & $0.11-0.117$ & 0.1807 & $0.15-0.198$ \\
\hline $\mathrm{Mn}$ & 0.0621 & $0.0563-0.0648$ & 0.0313 & $0.0311-0.0316$ & 0.0827 & $0.0771-0.0858$ & 0.0488 & $0.0466-0.0513$ \\
\hline $\mathrm{S}$ & 0.0938 & $0.0564-0.119$ & 0.0456 & 0.0434-0.0488 & 0.1027 & $0.052-0.149$ & 0.0472 & $0.0407-0.0518$ \\
\hline $\mathrm{Cl}$ & 0.0220 & $0.0118-0.0239$ & 0.0086 & $0.0042-0.0127$ & 0.0376 & $0.0086-0.0108$ & 0.0153 & $0.0086-0.0224$ \\
\hline $\mathrm{Zr}$ & 0.0367 & $0.0355-0.0383$ & 0.0193 & $0.0174-0.024$ & 0.0294 & $0.0288-0.0298$ & 0.0326 & $0.0321-0.0333$ \\
\hline $\mathrm{Ba}$ & 0.0239 & $0.0211-0.0277$ & 0.0195 & $0.0159-0.0218$ & 0.0244 & $0.0193-0.0305$ & 0.0233 & $0.013-0.0323$ \\
\hline $\mathrm{V}$ & 0.0073 & $0.0071-0.0076$ & 0.0051 & $0.0049-0.0053$ & 0.0096 & $0.0092-0.0104$ & 0.0063 & $0.0057-0.0068$ \\
\hline $\mathrm{Sr}$ & 0.0192 & 0.0184-0.0196 & 0.0133 & $0.0129-0.0135$ & 0.0140 & $0.0138-0.0142$ & 0.0197 & $0.0187-0.0203$ \\
\hline $\mathrm{Rb}$ & 0.0100 & $0.0095-0.0103$ & 0.0090 & 0.0089-0.0092 & 0.0104 & $0.0103-0.0106$ & 0.0102 & 0.0097-0.0107 \\
\hline $\mathrm{Zn}$ & 0.0064 & $0.0059-0.0067$ & 0.0031 & $0.0028-0.0035$ & 0.0073 & $0.0069-0.0077$ & 0.0075 & 0.0055-0.009 \\
\hline $\mathrm{Cr}$ & 0.0046 & $0.0042-0.0051$ & 0.0027 & $0.0023-0.0029$ & 0.0056 & $0.0053-0.0057$ & 0.0045 & $0.004-0.0051$ \\
\hline $\mathrm{La}$ & 0.0049 & $0.0038-0.0066$ & 0.0079 & $0.0052-0.0096$ & 0.0072 & $0.0052-0.0093$ & 0.0078 & $0.0074-0.0082$ \\
\hline $\mathrm{Ni}$ & 0.0026 & $0.0023-0.003$ & 0.0017 & $0.0015-0.002$ & 0.0036 & $0.0033-0.0037$ & 0.0026 & $0.0023-0.0028$ \\
\hline $\mathrm{Y}$ & 0.0022 & $0.002-0.0023$ & 0.0011 & $0.001-0.0012$ & 0.0025 & $0.0024-0.0026$ & 0.0021 & $0.0017-0.0024$ \\
\hline Mo & 0.0039 & $*_{-0.0057}$ & & & 0.0020 & $0.0019-0.0022$ & & \\
\hline $\mathrm{Pb}$ & 0.0021 & $0.0017-0.0024$ & & & 0.0025 & $0.002-0.0029$ & 0.0019 & $0.0017-0.0021$ \\
\hline Co & 0.0012 & $0.0013-0.0086$ & & & 0.0018 & $0.0017-0.002$ & 0.0009 & $0.00086-0.00094$ \\
\hline $\mathrm{Cu}$ & 0.0014 & $0.0013-0.0096$ & & & 0.0016 & $0.0013-0.0019$ & 0.0019 & $0.0012-0.0023$ \\
\hline $\mathrm{Ga}$ & 0.0014 & $0.0013-0.0016$ & & & 0.0016 & $0.0016-0.0017$ & 0.0016 & $0.0012-0.0014$ \\
\hline $\mathrm{Nb}$ & 0.0010 & $0.00098-0.0011$ & & & 0.0012 & $0.001-0.0014$ & 0.0011 & $0.001-0.0012$ \\
\hline $\mathrm{Bi}$ & & & & & 0.0012 & *-0.0012 & & \\
\hline $\mathrm{Pt}$ & & & 0.0023 & $*_{-0.0024}$ & & & 0.0016 & $*_{-0.0021}$ \\
\hline $\mathrm{Au}$ & & & 0.0024 & $*_{-0.0025}$ & & & & \\
\hline $\mathrm{Ce}$ & 0.0036 & $*_{-0.0039}$ & & & & & & \\
\hline $\mathrm{Sc}$ & 0.0012 & $*_{-} 0.0013$ & & & & & & \\
\hline
\end{tabular}

cooled, filling them in boric acid bottomed aluminum cups and put them into the tablet press to form pressed powder pellets under $30 \mathrm{Mpa}$ pressure.

Apparatus and operating conditions: The instrument (Thermo electron operation (us) ARL ADVANT XP+ WD$\mathrm{XRF}$ spectrometer) used in this work has a unique super sensitive range (100\% 0.001\%), high-power $(4.2 \mathrm{~kW})$ thin end-window $\mathrm{Rh} \mathrm{X}$-ray tube. In this study, working conditions were as follow:

Elements analysis range: $\mathrm{F} \sim \mathrm{U}$. excitation current was 50 $\mathrm{mA}$, excitation voltage was $50 \mathrm{kV}$ and relative humidity was $20 \%$.

Statistical analysis: The descriptive statistical parameters (mean, maximum and minimum concentrations) were calculated by Microsoft Excel 2010, Graph, $t$-test and the significant difference analysis among different soil types were performed by PASW statistic 18 .

\section{RESULTS AND DISCUSSION}

Overall analysis of elemental contents in soils: Total analysis, the determination of the total concentration(s) of an element (or elements) in a soil, is used to characterize a soil in terms of its fundamental elemental composition as derived from its parent geological material ${ }^{12}$. Table-1 shows the descriptive statistics, i.e., arithmetic mean and concentration range of the total concentrations of the 33 elements, qualitative and quantitative analyzed by XRF. The bar graph (Fig. 1) indicated the percentage of all the measured elements in black soil, sandy soil, brown soil and alluvial soil, respectively. From Table-1, we can see that black and brown soil contain relative large varieties and high content of elements, sandy soil contains less.

In terms of black soil, the content percentage of macronutrients, micronutrients, beneficial elements, pollution elements and other elements were 5.3788, 2.7115, 41.4319, 0.0067 and 0.5090 , respectively. The values of sandy soil, brown soil and alluvial soil, respectively, was 4.274, 1.5048, 42.5757, 0.0027, 0.3396, 4.205, 3.4581, 37.8415, 0.0081, $0.5431,4.472,2.1461,40.3975,0.0064,0.4721$. According to the analysis of variance, results showed in Table-2, there was no significant difference among the overall datasets.

Macronutrient contents of agricultural soils with reference to soil type: Generally, macronutrients refer to $\mathrm{C}$, $\mathrm{H}, \mathrm{O}, \mathrm{N}, \mathrm{P}, \mathrm{K}, \mathrm{Ca}, \mathrm{Mg}$ and $\mathrm{S}$, whose contents accounted for more than $0.1 \%$ of the dry weight of crops. Thus, they are always of the simple mineral constituents necessary for the 


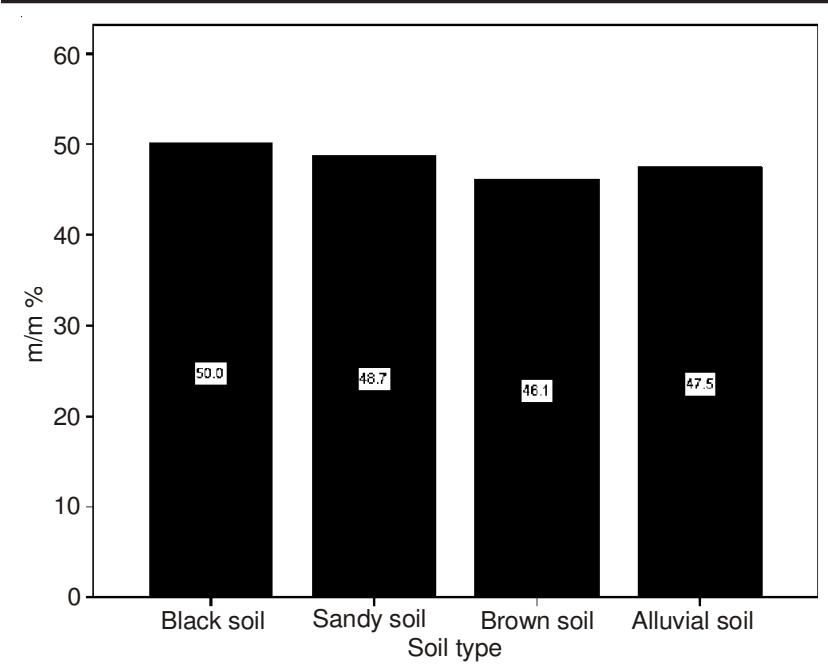

Fig. 1. Percentage of all the measured elements in soil

growth and development of the living plant ${ }^{13}$. Limited by the measuring range of instrument, $\mathrm{C}, \mathrm{H}, \mathrm{O}$ and $\mathrm{N}$ were given up.

TABLE-2

RESULTS OF TOTAL ELEMENTS CONTENT ANOVA

\begin{tabular}{lcc}
\hline \multicolumn{3}{c}{ Content } \\
\hline \multicolumn{3}{c}{ S-N-K } \\
\hline Soil types & $\mathrm{N}$ & Subset for alpha $=0.05$ \\
& & 1 \\
Brown soil & 33 & 1.403724 \\
Alluvial soil & 33 & 1.431124 \\
Sandy soil & 33 & 1.475652 \\
Black soil & 33 & 1.516306 \\
Sig. & \multicolumn{2}{c}{1.000} \\
\hline Means for groups in homogeneous subsets are displayed. \\
a. Uses Harmonic Mean Sample Size $=33$
\end{tabular}

Fig. 2 shows the content of macronutrients in different soil types. From the arithmetic means of soil elements in this figure associated with variance analyze $(p=0.975>0.05)$, conclusion was that elemental contents had no significant difference among soil types and so did the soil content range (Table-1).

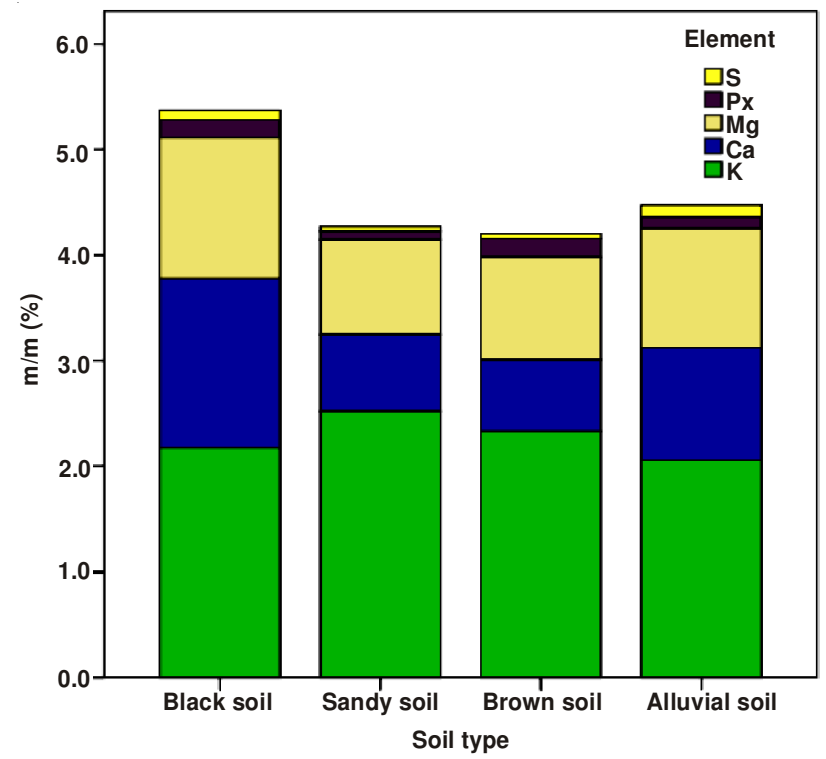

Fig. 2. Percentage content of macronutrients in different soil types
In terms of the total content of macronutrient elements, black soil had a relatively high content, $5.38 \%$, than other soil. The descending order of total content is black soil $>$ alluvial soil $>$ sandy soil $>$ brown soil. Black soil tends to have relatively high $\mathrm{Ca}$ and $\mathrm{Mg}$ content and relatively low $\mathrm{K}, \mathrm{S}$ and $\mathrm{P}$ content. Sandy soil had highest content of K, simultaneously the lowest content of S. All the elemental content of brown soil and alluvial soil were centered. As in dispensable material for plant growth, it's relatively harmonious content of inherent fertility for macronutrients, undoubtedly, has made black soil an excellent soil for crops plating. The relationship between macronutrients and plants demand has been tested in cabbages by Avalhães et al. ${ }^{14}$, the result of lack of macronutrient is, obviously, individual omissions of N, P, K or Ca were limiting for cabbage growth, considerably reducing plant height, number of leaves and shoot, root and whole plant dry mass.

Comparison of micronutrient, beneficial elements contents among four agricultural soil types: Even though the content of micronutrients in plants are lower than $0.1 \%$ of dry weight, they play an indispensable part in biochemical processes, as enzymes, hormones, vitamins, nucleic acid composition, to maintain the metabolic processes of plants and humans. Zinc, $\mathrm{Fe}, \mathrm{Mn}$ and $\mathrm{Cu}$ are essential nutrients and these deficiencies can strictly limit the mental and physical capacity of humans and adversely affect their health. Almost all of the nutrients that humans consume are derived from the soil-plant system ${ }^{15-18}$. So, the determination of micronutrients in soil are necessary. Table- 3 shows the Arithmetic mean of micronutrients of agricultural soils with reference to soil type. Analysis of variance was performed under 0.05 , among the four soil types. Result showed that there is no significant difference among the four soil types. According to Table-1 and Table-3, the content of $\mathrm{Fe}, \mathrm{Mn}, \mathrm{Cu}, \mathrm{Zn}, \mathrm{Ni}, \mathrm{Mo}, \mathrm{Cl}$, are very close and the range of content are very implicit. Content of $\mathrm{Fe}$ and $\mathrm{Mn}$ of brown soil had a relatively higher than other three types. Mo did not be detected in sandy and alluvial soil, so did $\mathrm{Cu}$ in sandy soil, black soil contains the lager content of Mo. In speaking of $\mathrm{Cu}, \mathrm{Zn}$ and $\mathrm{Ni}$, at low concentration, they were beneficial for crops, when beyond the concentration, they would hazard crops.

Table- 4 indicated the contents of arithmetic mean of beneficial elements of agricultural soils in different soil types. According to the study physiological functions of beneficial elements manipulated by Pilon-Smits et al. ${ }^{6}$. Beneficial elements refer to elements that promote growth and may be essential to particular taxa but are not required by all plants are called beneficial elements, the five most investigated beneficial elements are $\mathrm{Al}, \mathrm{Co}, \mathrm{Na}, \mathrm{Se}$ and $\mathrm{Si}$. Nowadays the definition of beneficial elements have been changing, with a detailed study, more and more finding prove that rare earth elements belonging to beneficial elements ${ }^{19,20}$. In the processing of quantitative analysis, Se was not detected in the all four soil types. Totally, black soil had the most varieties element, sandy soil deficiency of Mo, Co and Ce, but had the largest content of Si, brown soil lack of Co, alluvial soil lack of Mo and Ce. All the four soil types had the largest content of Si, which is compounding to Sommer et al. ${ }^{21}$, Silicon is one of the earth's most prevalent elements, comprising more than $25 \%$ of the earth's crust. 
TABLE-3

ARITHMETIC MEAN OF MICRONUTRIENTS OF AGRICULTURAL SOILS WITH REFERENCE TO SOIL TYPE

\begin{tabular}{|c|c|c|c|c|c|c|c|}
\hline \multirow[t]{2}{*}{ Soil types } & \multicolumn{7}{|c|}{ Elements $(\mathrm{m} / \mathrm{m} \%)$} \\
\hline & $\mathrm{Fe}$ & $\mathrm{Mn}$ & $\mathrm{Cu}$ & $\mathrm{Zn}$ & $\mathrm{Ni}$ & Mo & $\mathrm{Cl}$ \\
\hline Black soil & 2.6133 & 0.0621 & 0.0014 & 0.0064 & 0.0026 & 0.0039 & 0.0220 \\
\hline Sandy soil & 1.4600 & 0.0313 & nd & 0.0031 & 0.0017 & nd & 0.0086 \\
\hline Brown soil & 3.3233 & 0.0827 & 0.0016 & 0.0073 & 0.0036 & 0.0020 & 0.0376 \\
\hline Alluvial soil & 2.0700 & 0.0488 & 0.0019 & 0.0075 & 0.0026 & nd & 0.0153 \\
\hline Statistical significance & & & & & & & \\
\hline
\end{tabular}

TABLE-4

ARITHMETIC MEAN OF BENEFICIAL ELEMENTS OF AGRICULTURAL SOILS IN DIFFERENT SOIL TYPES

\begin{tabular}{|c|c|c|c|c|c|c|c|}
\hline \multirow{2}{*}{ Soil type } & \multicolumn{7}{|c|}{ Elements $(\mathrm{m} / \mathrm{m} \%)$} \\
\hline & $\mathrm{Si}$ & $\mathrm{Na}$ & $\mathrm{La}$ & $\mathrm{Y}$ & Mo & Co & $\mathrm{Ce}$ \\
\hline Black soil & 30.5967 & 1.3200 & 0.0049 & 0.0022 & 0.0039 & 0.0012 & 0.0036 \\
\hline Sandy soil & 33.2400 & 1.2633 & 0.0079 & 0.0011 & nd & nd & nd \\
\hline Brown soil & 26.6200 & 1.2600 & 0.0072 & 0.0025 & 0.0020 & 0.0018 & nd \\
\hline Alluvial soil & 29.8567 & 1.8167 & 0.0078 & 0.0021 & nd & 0.0009 & nd \\
\hline Statistical significance & & & & ns & & & \\
\hline
\end{tabular}

Comparison of pollution and other elements contents among four agricultural soil types: Table-5 shows the measured pollution elements in the four soil types, comparing to the median soil background elements value of Ji Lin province, the content of $\mathrm{Pb}$ in the four soil types were less than the median, the background soil value of $\mathrm{Pb}$ ranged from 17 to 49. The content of $\mathrm{Cr}$ was also nearby the background value. So far, the agricultural activities have not effected on the soil quality. We must recognize that all the soil samples were collected far away the industrial and wastewater irrigation. But farmers of this region have the habit of excessive use fertilizer, which ranges from $700 \mathrm{Kg} / \mathrm{hm}^{2}$ to $1000 \mathrm{Kg} / \mathrm{hm}^{2}$, the result may opposite to Zhong et al..$^{22}$ extensive use of fertilizers in agricultural production will result in soil heavy metals accumulated.

Table- 6 shows the Arithmetic mean of other elements of agricultural soils in different soil types. Elements content range of within groups was too low, even if it contained not measured

TABLE-5

ARITHMETIC MEAN OF POLLUTION ELEMENTS OF AGRICULTURAL SOILS IN DIFFERENT SOIL TYPES

\begin{tabular}{lcc}
\hline \multirow{2}{*}{ Soil type } & \multicolumn{2}{c}{ Element } \\
\cline { 2 - 3 } & $\mathrm{Cr}$ & $\mathrm{Pb}$ \\
\hline Black soil & 0.0046 & 0.0021 \\
Sandy soil & 0.0027 & nd \\
Brown soil & 0.0056 & 0.0025 \\
Alluvial soil & 0.0045 & 0.0019 \\
Back ground value & 0.00455 & 0.0027 \\
\hline
\end{tabular}

the elements differences of $t$-test were not evident. For less used in agriculture activities, these elements were mainly derived from parent rocks and fallen biological substances.

\section{Conclusion}

- In addition to organic matter, macronutrients, micronutrients and beneficial elements have made black soil a best candidate for crops planting.

- By contrasting the background value of pollution elements, under excessive usage of fertilizer, $\mathrm{Cr}$ and $\mathrm{Pb}$ had little concentration in all the four soil types.

- The function of Ti, Zr, Ba, V, Sr, Rb, Ga, Nb, Bi, Pt, Au, $\mathrm{Sc}$, in soil-plant should be further studied.

- The comparison of the elements suggested that the difference among soil types were mainly related to parent material. These findings can be used as basic information to maintain development of sustainable agriculture and promotion of environmental conservation.

\section{ACKNOWLEDGEMENTS}

The project was supported by the Key National Natural Science Foundation of China (No. 41130526). The authors thank Mr. Wang Guiman, Executive of Li Shu County Agricultural Technology Extension Station, for his collaboration in collecting soil samples and for valuable information on the soil samples investigated and Ms. Cui Ying and Liu Liru, for their valuable information on the distribution of soil type distribution Lishu county. The authors also thank the farmers for supplying soil samples and field information.

TABLE-6

ARITHMETIC MEAN OF OTHER ELEMENTS OF AGRICULTURAL SOILS IN DIFFERENT SOIL TYPES

\begin{tabular}{|c|c|c|c|c|c|c|c|c|c|c|c|c|}
\hline \multirow{2}{*}{ Soil type } & \multicolumn{12}{|c|}{ Element } \\
\hline & $\mathrm{Ti}$ & $\mathrm{Zr}$ & $\mathrm{Ba}$ & $\mathrm{V}$ & $\mathrm{Sr}$ & $\mathrm{Rb}$ & $\mathrm{Ga}$ & $\mathrm{Nb}$ & $\mathrm{Bi}$ & $\mathrm{Pt}$ & $\mathrm{Au}$ & $\mathrm{Sc}$ \\
\hline Black soil & 0.4083 & 0.0367 & 0.0239 & 0.0073 & 0.0192 & 0.0100 & 0.0014 & 0.0010 & nd & nd & nd & 0.0012 \\
\hline Sandy soil & 0.2687 & 0.0193 & 0.0195 & 0.0051 & 0.0133 & 0.0090 & nd & nd & nd & 0.0023 & 0.0024 & nd \\
\hline Brown soil & 0.4513 & 0.0294 & 0.0244 & 0.0096 & 0.0140 & 0.0104 & nd & 0.0012 & 0.0012 & nd & nd & nd \\
\hline Alluvial soil & 0.3757 & 0.0326 & 0.0233 & 0.0063 & 0.0197 & 0.0102 & 0.0016 & 0.0011 & nd & 0.0016 & nd & nd \\
\hline Statistical significance & \multicolumn{12}{|c|}{ ns } \\
\hline
\end{tabular}

Note: ns indicates "no significant" among contents of elements 


\section{REFERENCES}

1. A. Kabata-Pendias, Geoderma, 122, 143 (2004).

2. J. Yanai, T. Okada and H. Yamada, Soil Sci. Plant Nutr., 58, 1 (2012).

3. G.Y. Wang, M. Pan, X.D. Liu, H.H. Lian, Y.Z. Wu and Z.Y. Shun, Acta Sci. Nat. Univ. Pekinensis, 28, 475 (1992).

4. S.L. Li, Y.B. Zhang, Y.K. Rui and X.F. Chen, Int. J. Experim. Bot., 81, 41 (2012).

5. G.J. Zhang, X.M. Song, Z.H. Zhou, W.B. Liu and Y.L. Luo, Earth Environ., 39, 498 (2011).

6. E.A. Pilon-Smits, C.F. Quinn, W. Tapken, M. Malagoli and M. Schiavon, Curr. Opin. Plant Biol., 12, 267 (2009).

7. E.P. Inyang, O.O. Oketayo and E.I. Obiajunwa, Soil Tillage Res., 124 178 (2012).

8. K.P. Kutsenogyi, R.P. Makarikova, L.I. Milyutin, N.B. Naumova, V.V. Tarakanov and O.V. Chankina, Nucl. Instrum. Methods Phys. Res. A, 575, 214 (2007).

9. T.D. Hettipathirana, Spectrochim. Acta B, 59, 223 (2004).

10. N.K. Saini, P.K. Mukherjee, M.S. Rathi, P.P. Khanna and K.K. Purohit, J. Trace Microprobe Tech., 20, 539 (2002).
11. A.M. Ure, J. Anal. Chem., 337, 577 (1990).

12. L. Zheng, Trace elements in Chinese Soil, Jiangsu Science and Technology Publishing House, Nanjing, pp. 280-305 (1996).

13. T.C. Broyer and P.R. Stout, Ann. Rev. Plant Physiol., 10, 277 (1959)

14. C.C. Avalhães, R. de M. Prado, L.M. Romualdo, D.E. Rozane and M.A.R. Correia, Biosci. J., 25, 21 (2009).

15. R.D. Graham, R.M. Welch and H.E. Bouis, Adv. Agron., 70, 77 (2001).

16. R.M. Welch, Plant Soil, 247, 83 (2002).

17. R.M. Welch and R.D. Graham, Plant Soil, 245, 205 (2002).

18. C.Q. Zou, F.S. Zhang, Y.M. Zuo, X.P. Gao and M.S. Fan, in eds.: G.S. Banuelos and Z.-Q. Lin, Soil and Crop Management for Improving Iron and Zinc Nutrition of Crops. In: Development and Uses of Biofortified Agricultural Products. CRC, Boca Raton, pp. 71-93 (2008).

19. G. Tyler, Plant Soil, 267, 191 (2004).

20. B.X. Huang, X.M. Xie, J.B. Cai and L. Xu, Chin. Rare Earths, 20, 45 (1999).

21. M. Sommer, D. Kaczorek, Y. Kuzyakov and J. Breuer, J. Plant Nutr. Soil Sci., 169, 310 (2006).

22. L.Y. Zhong and L.Z. Guo, Ecol. Environ. Sci., 20, 1934 (2011). 